\title{
Redactioneel
}

\section{(Ook) het toezicht gaat door}

\author{
Marije Batting en Joep Beckers*
}

Het blijven bevreemdende tijden. Ondanks dat de coronacrisis inmiddels al maanden voortduurt, zijn we er nog steeds niet helemaal aan gewend. Gek is dat overigens niet echt. De ontwikkelingen blijven elkaar in rap tempo opvolgen. $\mathrm{Na}$ de zomer met een voornamelijk positief sentiment te hebben afgetrapt - met volle terrassen, winkelstraten en campings tot gevolg - is het aantal besmettingen de afgelopen tijd weer flink toegenomen. De reguliere zorg wordt weer verdrongen door coronagerelateerde zorg. En verschillende sectoren beginnen te piepen en kraken. We snakken met z'n allen naar licht aan het einde van deze lange tunnel.

Wie denkt dat het toezicht stilstaat, die heeft het mis. Ook het toezicht past zich aan. Zowel op intern organisatorisch vlak, als in de buitenwereld. Intern zijn toezichthouders druk bezig met een nieuwe invulling van het fenomeen 'kantoor'. Want als de afgelopen maanden iets hebben aangetoond, dan is het dat werken op afstand voor veel toezichthouders in veel gevallen prima functioneert. Het aanpassingsvermogen bleek groot. Maar nu het stof neerdaalt, het uitzonderlijke normaal wordt, en de grenzen van ieders tolerantievermogen in beeld komen, doet ook het gemis van een kantoor zich steeds meer voelen. Daarbij wordt 'kantoor' niet langer of in ieder geval veel minder gezien als een verzameling werkplekken, maar als een ontmoetingsplek. Een ontmoetingsplek die de creativiteit moet stimuleren en vooral de sociale cohesie moet borgen. Als redactie kijken we stiekem al uit naar de transformaties die onze kantoorgebouwen zullen ondergaan. En ook de eerste vacatureteksten zijn al gesignaleerd waarin toezichthouders zich aan een steeds nationaler en zelfs internationa-

Mr. M.L. Batting is advocaat-partner bestuursrecht bij Pels Rijcken \& Droogleever Fortuijn en redacteur van het Tijdschrift voor Toezicht. Dr. J. Beckers is gedragswetenschapper en manager Toezicht Zorgaanbieders bij de NZa en hoofdredacteur van Tijdschrift voor Toezicht. ler publiek presenteren als excellente werkgevers die hun medewerkers maximale vrijheid en flexibiliteit willen bieden, inclusief excellente faciliteiten ten behoeve van het werken op afstand, maar ook een inspirerend 'thuishonk' (= kantoor).

Ook het toezicht zelf evolueert. Fysieke inspecties en toezichtsbezoeken zijn deels geannuleerd, deels anders vormgegeven (incl. coronaprotocol!), en deels vervangen door 'off-site' inspecties en toezichtsbezoeken. Dat is wennen, maar past misschien ook wel in een trend die eigenlijk al langer gaande was, en nu in een stroomversnelling is terechtgekomen. Want vrijwel iedere toezichthouder heeft prominent in zijn missie en visie staan dat hij datagedreven wil werken. En datagedreven werken kan over het algemeen prima op afstand. Hieraan kleven echter ook risico's. Zo vraagt datagedreven werken veel van de datakwaliteit. En vrijwel iedere toezichthouder moet soms nog werken met onvolledige, onbetrouwbare en gedateerde data. Dus net als voor het thuis- en op kantoor werken, geldt ook voor het toezicht dat het zoeken is naar de optimale balans tussen datagedreven toezicht en risicogestuurde 'klassieke' inspecties en toezichtbezoeken. Deze zoektocht zal ongetwijfeld nog wel even voortduren.

Nog beter dan effectief toezicht, is het wanneer ondertoezichtgestelden zich vanzelf of spontaan aan de voor hen geldende normen houden. Wassenburg, Beke, Pret en Müller gaan in hun artikel in op de vraag waarom dronepiloten dat nog niet altijd doen. Waarom vliegen sommige dronepiloten soms toch in no fly zones? Het antwoord op deze vraag blijkt gelegen in het feit dat dronepiloten sceptisch zijn tegenover de bestaande regelgeving en het aantal no fly zones. Daarnaast zijn dronepiloten beperkt bereid om moeite te stoppen in de benodigde voorbereiding van de vlucht, waardoor zij sneller overtredingen begaan. De auteurs bespreken hoe toezichthouders deze inzichten kunnen gebruiken om 
tot effectieve gedragsinterventies te komen, met spontane regelnaleving tot gevolg.

Het artikel van Wassenburg e.a. illustreert mooi hoe het toezicht rekening kan houden met de context waarin een ondertoezicht gesteldefunctioneert. En dat laatste is ook het thema van de bijdrage van Ketelaars, Spronk en Leistikow. Laatstgenoemden ontwikkelden op basis van conceptanalyse, literatuuronderzoek, documentstudie, interviews en focusgroepen het kader 'Context van een zorgaanbieder'. Dit kader geeft inspecteurs van de Inspectie Gezondheidszorg en Jeugd (IGJ) handvatten om af te wegen of en hoe de context invloed heeft op het vertrouwen in zorgaanbieders. En om vervolgens gerichte toezichtsinterventies te kunnen inzetten. Maar ook buiten het zorgdomein speelt de context natuurlijk een rol, dus ook andere toezichthouders kunnen hun voordeel doen met het kader dat zij ontwikkelden.

Ook Van der Voort en Sedee ontwikkelden een model. In hun geval betreft het echter een model dat kan worden gebruikt om de effecten van datagedreven risicogebaseerd toezicht inzichtelijk te maken. Het door Van der Voort en Sedee ontwikkelde model bevestigt dat datagedreven toezicht in potentie de effectiviteit van toezicht kan vergroten. Maar het model waarschuwt ook voor vertekeningen, als toezichthouders met datagedreven toezicht alleen data van risicovolle bedrijven bemachtigen en gebruiken. De auteurs bepleiten dan ook een balans tussen datagedreven risicogebaseerd toezicht en willekeurige inspecties en toezichtsbezoeken. Van een geheel andere orde is de bijdrage van Duijkersloot. Vier jaar geleden trad de Algemene Verordening Gegevensbescherming (AVG) in werking. Twee jaar later werd deze verordening van toepassing verklaard. Hoog tijd dus om een eerste tussenbalans op te maken. Duijkersloot gaat daarbij specifiek in op de bestuurlijke beboeting van overheden. Daarbij staat een aantal vragen centraal, zoals welke mogelijkheden en beperkingen het Nederlands recht in algemene zin en de Autoriteit Persoonsgegevens (AP) als de aangewezen toezichthouder kennen als het gaat om het bestuurlijk beboeten van overheden, maar ook in hoeverre onze privacytoezichthouder overheden tot dusverre überhaupt heeft beboet. Van het artikel van Duijkersloot is het een kleine stap naar de volgende etappe van onze grote toezichtsinterviewestafette. Ditmaal sprak de redactie namelijk met de Autoriteit Persoonsgegevens. En meer specifiek met Monique Verdier, sinds 1 februari 2019 vicevoorzitter, en Katja Mur, sinds 1 januari 2019 lid van de raad van bestuur. In een wederom zeer inspirerend gesprek wordt vooral ingegaan op hoe privacy zich verhoudt tot andere publieke waarden en op de rol van privacy in de huidige coronacrisis.

De coronacrisis vormt ook de aanleiding voor de bijdrage van De Ridder. Tegen de achtergrond van de in de zomer versoepelde coronamaatregelen bespreekt De Ridder in haar column het dilemma dat 'meer mogen' ook gepaard gaat met 'meer moeten'. Het handhaven van de anderhalvemetersamenleving terwijl vrijwel alles weer mag, is volgens De Ridder een grote uitdaging. Hoe kunnen we mensen helpen zich te gedragen naar de geldende richtlijnen? Duidelijk is in ieder geval dat mensen eraan moeten worden herinnerd dat het oude normaal (helaas) nog niet terug is.

En ook dit nummer sluit traditiegetrouw af met een notenkraker. In zijn bijdrage gaat Stijnen in op de rechtspraak waaruit volgt dat het zwijgrecht alleen toekomt aan formele bestuurders. Deze beperkte opvatting van het zwijgrecht heeft consequenties voor het gebruik van de verklaringen van werknemers. Met het oog op beboeting van de onderneming, blijven dergelijke verklaringen onverminderd staan, zo schrijft Stijnen. 